\title{
Littoral mayfly assemblages in South-East European man-made lakes
}

\author{
Marina VILENICA, ${ }^{1}$ Natalija VUČKOVIĆ, ${ }^{2}$ Zlatko MIHALJEVIĆ ${ }^{2 *}$ \\ ${ }^{1}$ University of Zagreb, Faculty of Teacher Education, Trg Matice hrvatske 12, Petrinja; ${ }^{2}$ University of Zagreb, Faculty of Science, \\ Department of Biology, Rooseveltov trg 6, Zagreb, Croatia
}

\begin{abstract}
Man-made freshwater habitats have been widely used to successfully modify the environment for human benefit, including purposes of irrigation, flood control or electricity generation. Over the past decade, our knowledge about the mayfly fauna and its ecology in South-East Europe has been growing, yet the data related to lentic assemblages remain very scarce. In this study, littoral mayfly assemblages were investigated at artificial and heavily modified lentic habitats in the Dinaric Western Balkan ( $\mathrm{n}=21)$ and Pannonian Lowland $(n=15)$ ecoregions. Mayfly nymphs were sampled during the summer months of 2016 or 2017. At each sampling site, ten samples were collected using a benthos hand net. A total of 21 mayfly species were recorded, though species richness per site was rather low (i.e., between zero and seven species). Cloeon dipterum (Linnaeus, 1761) was the most frequent species recorded, while Caenis horaria Linnaeus, 1758 was the most abundant. This study showed that the Croatian mayfly fauna is still growing, with the first record of Siphlonurus aestivalis Eaton, 1903 for the country. The assemblage structure was mainly dominated by lower reaches and lentic (potamal and littoral) elements and detritivores (gatherers/collectors and active filter feeders). Orthophosphates and chemical oxygen demand had the highest influence on mayfly assemblages, reflecting a higher level of pollution at sites in the Pannonian Lowland ecoregion, and consequently markedly lower mayfly abundances. As mayflies are widely used as bioindicators of freshwater ecosystems, detailed information about their assemblages in heavily modified and artificial habitats could contribute to future conservation activities of freshwater habitats and their communities. Additionally, these results could be applied in creating a monitoring system for artificial lakes according to the requirements of the European Water Framework Directive.
\end{abstract}

\section{INTRODUCTION}

Historically, man-made freshwater habitats have been widely used to successfully modify the environment for human benefits, such as recreational purposes, fish farming, flood control, irrigation or as a source of drinking water for livestock (Seaman and Sprague, 1991; Petrere, 1996). In recent years, reservoirs are the most commonly created artificial water-bodies (Schwarz, 2012),

Corresponding author: zlatko.mihaljevic@biol.pmf.hr

Key words: Habitat degradation; lentic habitats; species richness; environmental factors; new records.

Contributions: ZM, designed and supervised the research; MV, identified the specimens, analysed the data and wrote the paper; $\mathrm{ZM}, \mathrm{NV}$, collected samples; NV, sorted samples. All authors edited the drafts and approved the final version of the manuscript.

Edited by: Stefano Fenoglio, University of Piemonte Orientale, Alessandria, Italy

Received: 26 August 2018.

Accepted: 7 Dicember 2018.

This work is licensed under a Creative Commons Attribution NonCommercial 4.0 License (CC BY-NC 4.0).

CCopyright M. Vilenica et al., 2019

Licensee PAGEPress, Italy

J. Limnol., 2019; 78(1): 47-59

DOI: 10.4081/jlimnol.2019.1853 predominantly formed by using a dam or a lock to store water, for the primary purpose of electrical energy generation (Petrere, 1996). Reservoirs are complex systems that represent a transition between lakes and rivers (Wetzel, 2001; Irz et al., 2002) and their shores are most commonly altered. In most cases, water over the dam loses its lotic properties such as flow and mechanical aeration and becomes slow-flowing (Polak, 2004). Damming causes greater hydrological changes, such as river basin erosion downstream, rising water temperatures and increased sedimentation and water fluctuations (Petts, 1984; Wang and Hu, 2009; Carmignani and Roy, 2017). The impoundment has a higher nutrient intake, which accelerates eutrophication, frequently resulting in oxygen deficiency and reduced water transparency (Wiatkowski, 2011). These changes in turn modify the composition and structure of biological communities and their lower diversity (Baxter, 1977; Vollenweider and Kerekes, 1982; Brittain and Saltveit, 1989; Wetzel, 2001, Céréghino et al., 2002; Poff and Zimmerman, 2010) and disable certain important ecological processes, such as fish migration. Sensitive taxa are lost, while tolerant taxa prevail, producing assemblage turnover (Davies and Jackson, 2006; King and Baker, 2014). The inhabiting communities often show signs of "rhithralization" (e.g. caused by channel straightening) or "potamalization" (e.g. caused by impounding). For instance, when the distribution of longitudinal zonal associations and/or trophic structure of a certain river zone differs from its reference state, the river system has been altered indicating a certain level of ecological disturbance (Moog, 
2002). Nevertheless, certain researchers (Baxter, 1977; Irz et al., 2006, Vilenica et al., 2016a) argue that heavily modified and artificial lentic habitats could also be important from the biodiversity conservation aspect, as they provide habitats for many animal species (birds, fish, insects etc.) and affect the enhanced development of surrounding vegetation.

Inhabiting a wide range of freshwater habitats, mayflies are often one of the most abundant taxonomic groups, contributing approximately $25 \%$ of the total benthic macroinvertebrate production (Elliott et al., 1988). Their species richness is generally much higher in lotic habitats, especially in the upper reaches (rhithral sections) of fastflowing streams and rivers, and lower reaches (potamal sections) of slow-flowing natural lowland rivers. On the other hand, springs (crenal sections) and lentic habitats harbour much lower mayfly species richness (Bauernfeind and Moog, 2000; Bauernfeind and Sóldan, 2012). In accordance with the available microhabitats, which offer different food resources, the composition of mayfly assemblages will be composed of varying ratios of grazers/scrapers, gatherers/collectors and filter feeders (Bauernfeind and Sóldan, 2012; Vilenica et al., 2018). Grazers/scrapers consume epilithic algae and fine particulate organic matter (FPOM), while detritivores (gatherers/collectors, active and passive filter feeders) feed on decomposing coarse particulate organic matter (CPOM) and FPOM (Lamp and Britt, 1981; Buffagni et al., 1995; Bauernfeind and Soldán, 2012).

In order to develop effective conservation and management of freshwater habitats, biological assessments are highly recommended (Hughes et al., 1986; Stoddard et al., 2008). Numerous studies have shown that mayflies are highly sensitive to anthropogenic alterations of their habitats, and are among the first benthic macroinvertebrates to disappear (Di Giovanni et al., 2003; Brittain and Sartori, 2003). Consequently, they have been widely used as a particularly valuable taxonomic group for biomonitoring programmes (Lenat, 1988; Lenat and Penrose, 1996, Bauernfeind and Moog, 2000; Ferro and Sites, 2007). This study was conducted in the framework of the project "Development of a classification system to assess the ecological potential of artificial and heavily modified surface water bodies", intended to provide much-needed information on the ecology of benthic biota, including mayflies, in man-made lentic habitats. Moreover, Croatia has few natural, large, lentic habitats (i.e. lakes), and some artificial habitats are already proving to be important habitats for certain rare aquatic insects, such as dragonflies (Vilenica et al., 2016a).

Therefore, the aims of this study were to: i) identify mayfly species richness and distribution, ii) analyse the composition and structure of mayfly assemblages (in terms of longitudinal zonal associations and feeding groups), and iii) determine the main environmental factors that influence mayflies in the studied man-made lakes.

\section{METHODS}

\section{Study area}

The study encompassed a total of 36 man-made lakes, of which 21 were located in the Dinaric Western Balkan ecoregion (ER 5) and 15 in the Pannonian Lowland ecoregion (ER 11) (Illies, 1978) (Figs. 1 and 2). The majority of these sites are reservoirs built on smaller or larger rivers, while several are anthropogenicallyimpacted natural lakes (e.g., Prološko Blato, Sakadaš, Njivice) or artificial lakes and gravel pits (e.g., Ponikve, Šoderica Koprivnica, Rakitje, Novo Čiče).

\section{Sampling protocol}

Mayfly nymphs were sampled together with other benthic macroinvertebrates, during the low water period from July to September in 2016 or 2017. At all 36 study sites, the littoral zone was sampled at two or more locations (depending on reservoir size). Sampling was conducted by applying a modified proportional stratified sampling approach (Urbanič et al., 2012).

Each sampling location covered an area of $25 \mathrm{~m}$ lakeshore up to $1 \mathrm{~m}$ depth. At each location, ten replicates were collected using a benthic hand net $(25 \times 25 \mathrm{~cm}$ surface area, $500 \mu \mathrm{m}$ mesh-size). Samples were taken in microhabitats covering at least $10 \%$ of the area, proportionate with their coverage at the sampling sites. We defined the substrate categories according to the AQEM consortium (2002). To generate the "lithal" variable, we summed up the coverage percentages of the megalithal, macrolithal, mesolithal and microlithal. To generate the "fine sediment" variable, we summed the coverage percentages of the akal, psammopelal, pelal and psammal substrate (Tab. 1).

Mayflies were identified to the lowest possible taxonomical level (very juvenile and/or very damaged individuals were identified only to the genus level) using e.g. Malzacher (1984) and Bauernfeind and Humpesch (2001). All voucher specimens are deposited at the Department of Biology, Faculty of Science, University of Zagreb, Croatia.

\section{Environmental parameters}

At the littoral zone of each study site, the following environmental parameters were measured at the time of benthic macroinvertebrate sampling: water temperature, dissolved oxygen concentration (using the oximeter WTW Oxi 330/SET), conductivity (with the conductivity meter WTW LF 330) and pH (using the pH-meter WTW 


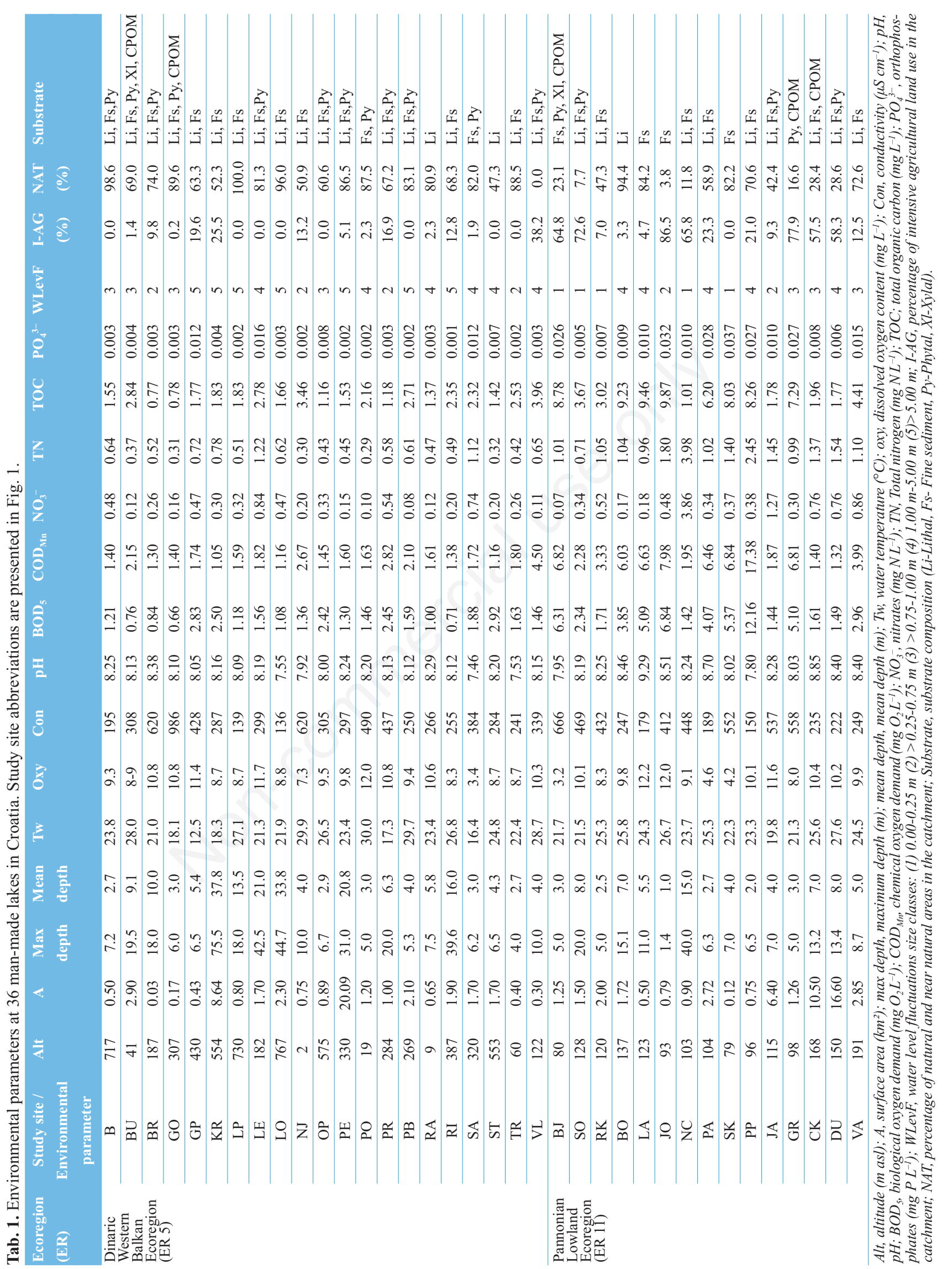


ph 330). The remaining environmental parameters are presented as the mean value of six composite samples from the euphotic zone collected over a six-month period (April-September 2016 or 2017) (Tab. 1). Water chemistry analyses were carried out according to the APHA standard methods (1992). Variables describing land use in catchments were calculated with GIS tools, using the Corine Land Cover classification (CLC Hrvatska, 2013).

Two categories of land use were distinguished: natural and semi-natural areas (CLC classes 3, 4, and 5), and areas characterized by intensive agricultural practices (CLC categories 2.1, 2.2, 2.4.1 and 2.4.2). Seasonal water level fluctuation values were grouped into five categories: (1) 0.00-0.25 m, (2) 0.25-0.75 m, (3) 0.75-1.00 m, (4) 1.00 $5.00 \mathrm{~m},(5)>5.00 \mathrm{~m}$ (Tab. 1) (Peterlin and Urbanič, 2013).

\section{Data analyses}

The similarity of mayfly assemblages between study sites was examined using Hierarchical cluster analysis (HCA) and non-metric multidimensional scaling (NMDS) ordination based on the Bray-Curtis similarity matrix. Species data were log transformed prior to analyses. Only sites with mayfly records were included in the analysis.

In order to determine river influence on lentic waterbodies and their assemblages, the composition of mayfly assemblages was examined in terms of trophic structure and longitudinal zonal associations of species at each study site (using the classification of Buffagni et al., 2009, 2018). The longitudinal zonal association and functional feeding group of each individual species are presented as a proportion within the assemblage. Most

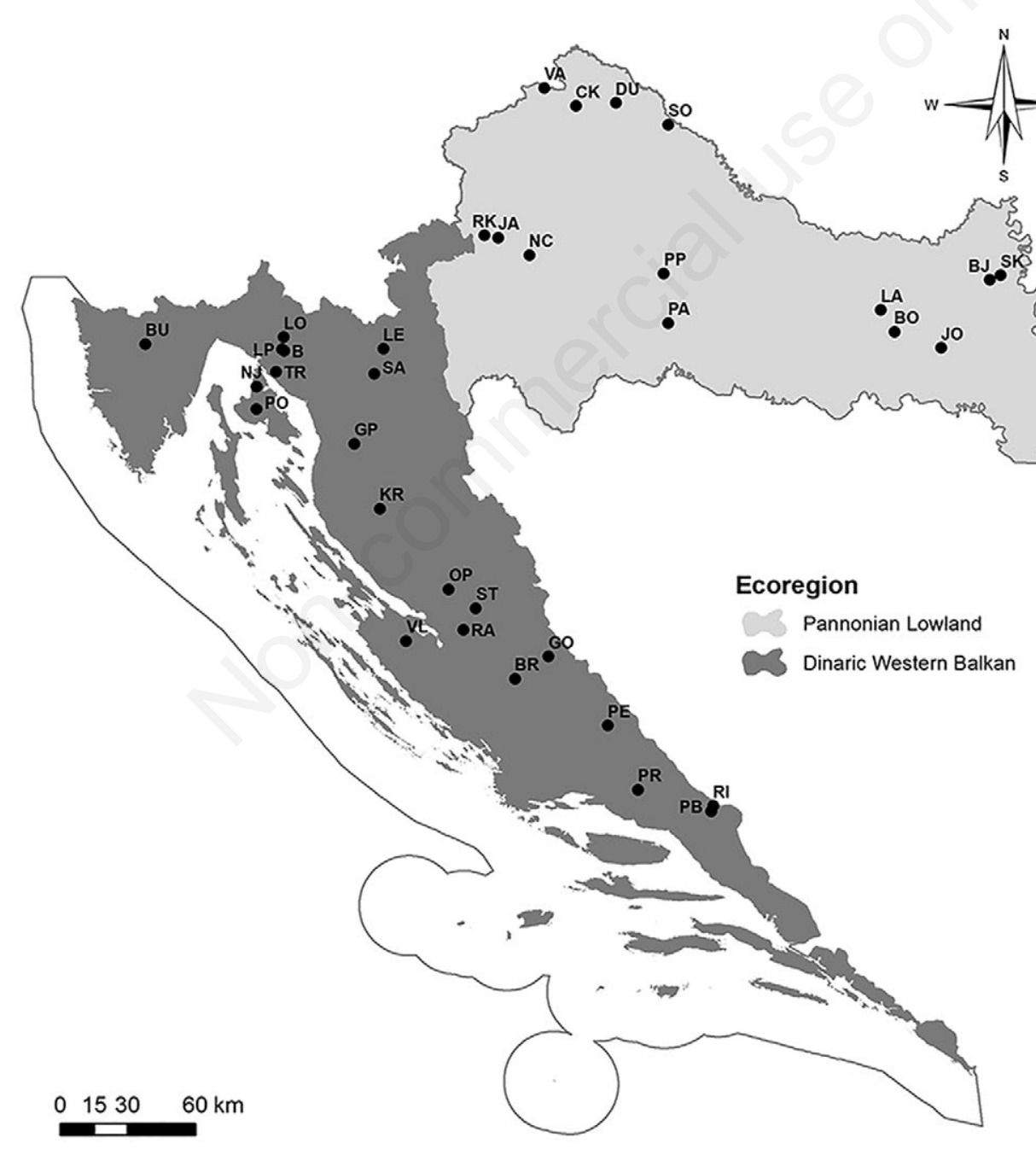

Fig. 1. Geographical position and locations of the 36 study sites. Study sites: ER 5: B, Bajer; BU, Butoniga; BR, Brljan; GO, Golubić; GP- Gusić polje; LP, Lepenica; LE, Lešće; LO, Lokve; NJ, Njivice; OP, Opsenica; PE, Peruća; PO, Ponikve; PR, Prančević; PB, Prološko blato; RA, Razovac; RI, Ričice; SA, Sabljaci; ST, Štikada; TR, Tribalj; VL, Vlačine. ER 11: BJ, Biljsko jezero; SO, Šoderica Koprivnica; RK, Rakitje; BO, Borovik; LA, Lapovac; JO, Jošava; NC, Novo Čiče; PA, Pakra; SK, Sakadaš; PP, Popovac; JA, Jarun; GR, Grabova; CK, Čakovec; DU, Dubrava; VA, Varaždin. 
taxa do not occur exclusively in one biocoenotic region and do not feed exclusively on a single food resource. Therefore, the assignment of taxa to a particular category is based on the ten-point assignment scale (see SchmidtKloiber and Hering, 2015). Using the given points and percentage of each species within the assemblage, the longitudinal zonation preferences and functional feeding group composition of mayfly assemblages at each study site were calculated.

Canonical correspondence analysis (CCA) was used to ordinate mayfly occurrence with respect to environmental variables. The analysis was performed using data for 21 taxa (rare species were downweighed) and 16 environmental variables. The Monte Carlo permutation test with 499 permutations was used to test the statistical significance of the relationship between all taxa and all variables. The Pearson's correlation coefficient was applied to examine the strength and significance of the reservoir land cover catchment characteristics and orthophosphates as the major eutrophication driver.

The Bray-Curtis similarity index, HCA and NMDS analyses were conducted in Primer 6 (Clarke and Gorley, 2006). The CCA analysis was performed using CANOCO 5.00 (ter Braak and Šmilauer, 2012). Pearson's coefficient of correlation was calculated using Statistica 10.0 (Statsoft, 2010). All figures were processed with Adobe Illustrator CS6.

\section{RESULTS}

\section{Mayfly assemblages}

A total of 27,769 individuals were collected and identified, belonging to 21 species (Tab. 2). The number of individuals is presented per meter square (Tab. 2). The most widespread was Cloeon dipterum (Linnaeus, 1761), recorded at 27 study sites, while Caenis horaria Linnaeus,

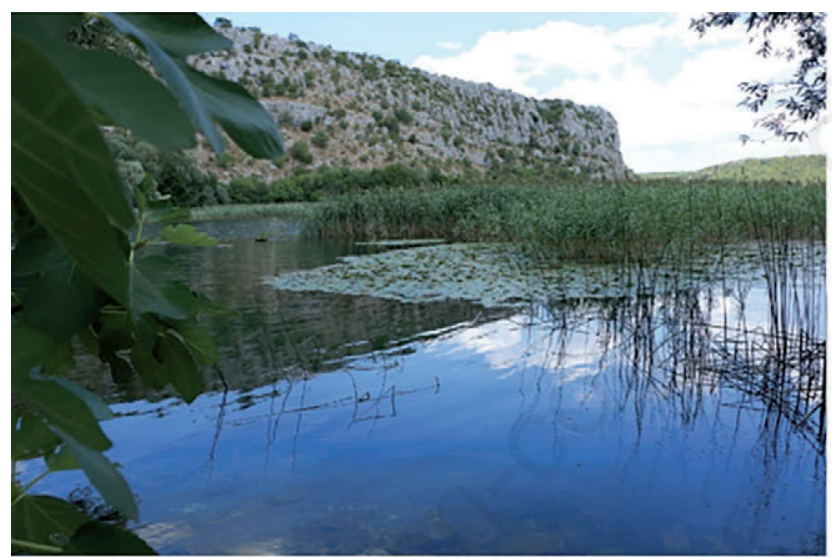

a)

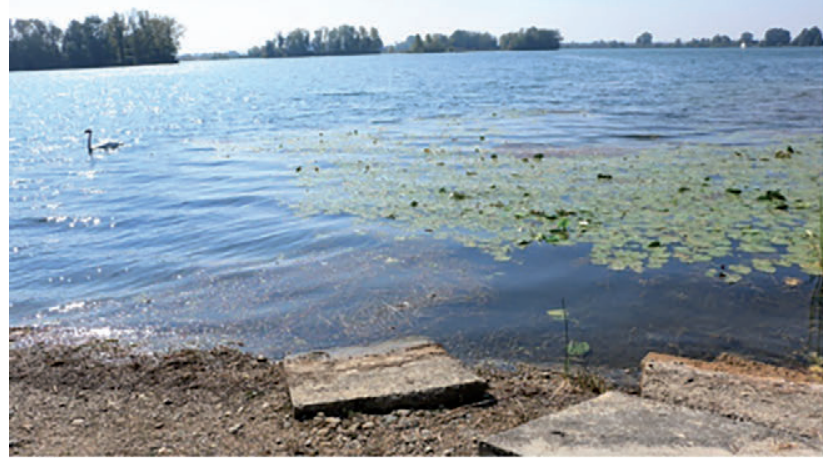

c)

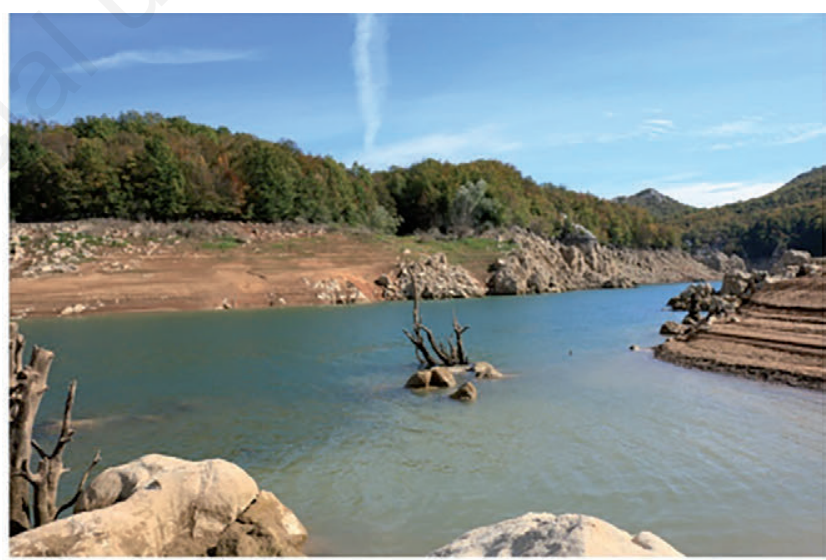

b)

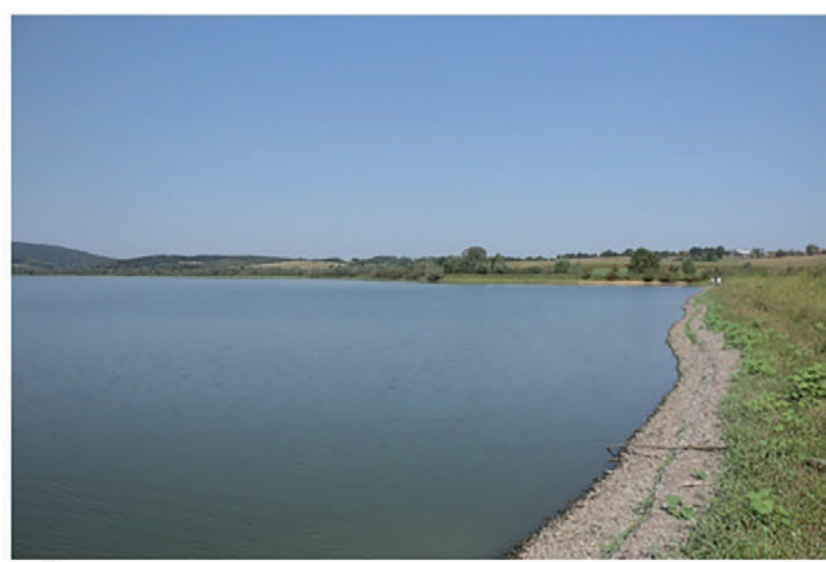

d)

Fig. 2. Examples of the study sites in the Dinaric Western Balkan ecoregion a) Brljan, b) Krušćica and in the Pannonian Lowland ecoregion c) Šoderica Koprivnica and d) Popovac. 


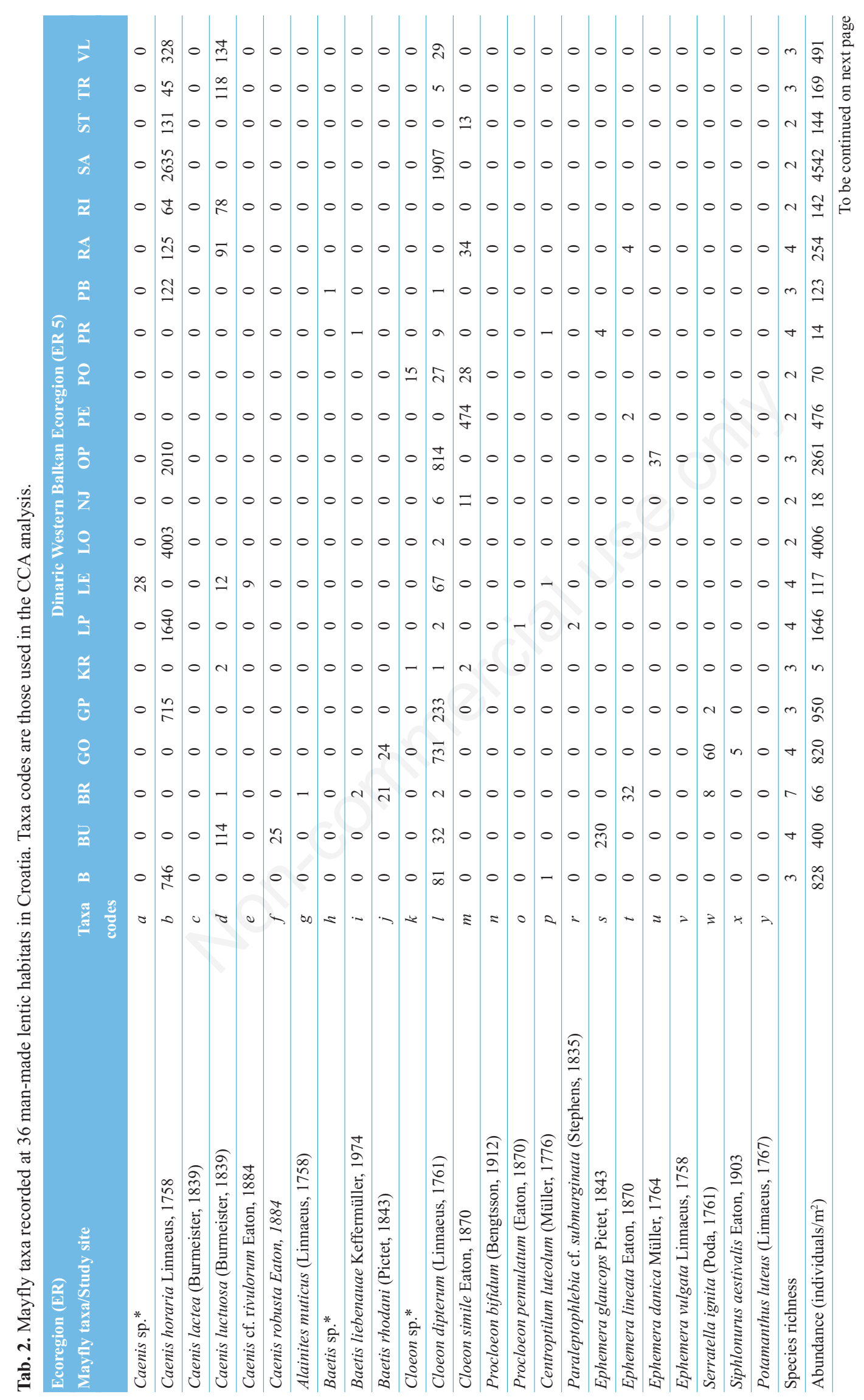




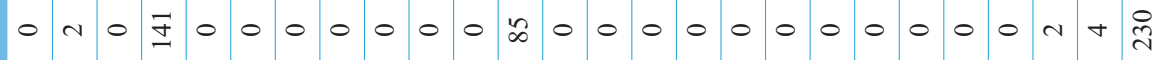

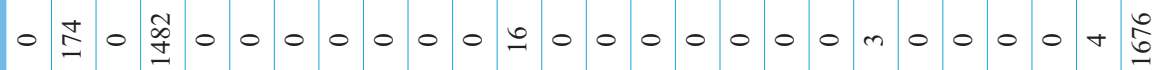

$\frac{1}{0}$

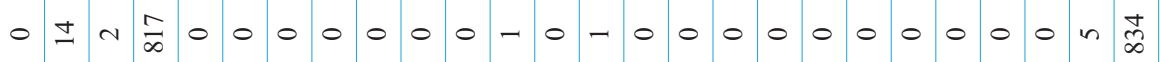

$\frac{\approx}{0}$

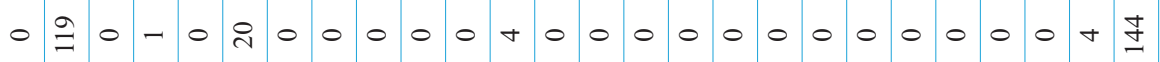

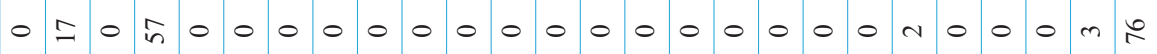
00000000000000000000000000

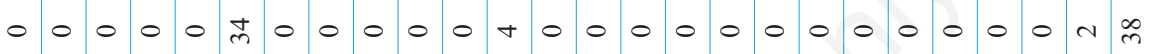

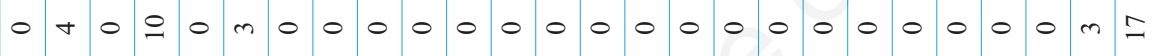

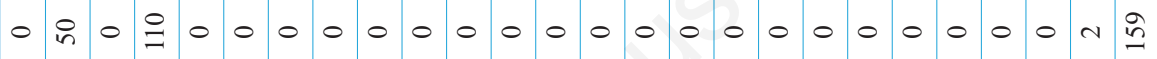

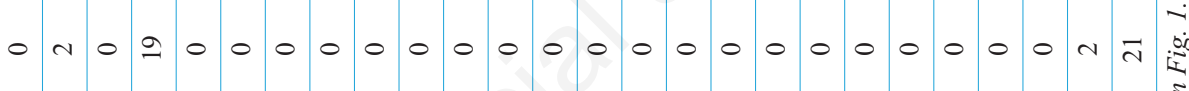
0 om in $0000000-000000000000 m b$

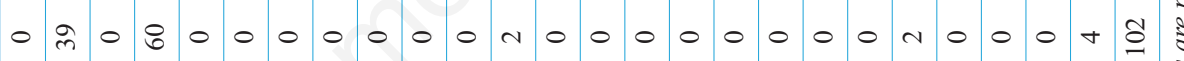

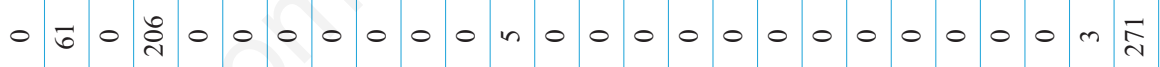

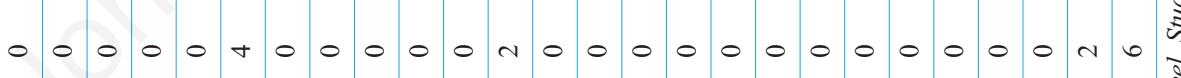

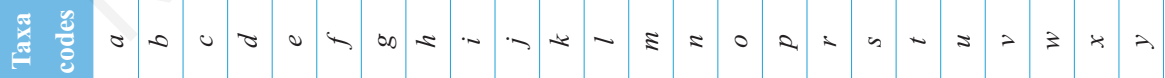


1758 was the most abundant. Several species were recorded at a single site, with Alainites muticus (Linnaeus, 1758), Procloeon bifidum (Bengtsson, 1912) and P. pennulatum (Eaton, 1870) as the rarest species (Tab. 2). The record of Siphlonurus aestivalis Eaton, 1903 is a first for Croatia.

Species richness ranged between zero species recorded at Popovac and seven at Brljan. Abundance was highest at Sabljaci (4542 individuals $/ \mathrm{m}^{2}$ ), and lowest at Krušćica (5 individuals $/ \mathrm{m}^{2}$ ), both located in the Dinaric Western Balkan ecoregion. Nevertheless, sites in this ecoregion had markedly higher abundance than sites in the Pannonian Lowland ecoregion (Tab. 2).

A $20 \%$ similarity of mayfly assemblages was recorded among the study sites. In NMDS analysis (Fig. 3, 2D stress $=0.1$ ), sites were partially grouped in several clusters with $40 \%$ similarity based on their position in one of the ecoregions.

At the majority of sites, assemblage structure was dominated by lower reaches and lentic elements (potamal and littoral elements), and by detritivores (gatherers/ collectors and active filter feeders) (Fig. 4). Golubić, Lešće and Prančević had a higher percentage of spring and upper reaches (crenal and rhithral) elements compared to other sites, while Golubić, Peruća, Njivice and Ponikve had similar shares of grazer/scrapers and detritivores.

\section{Mayflies and environmental variables}

The results of the ordination of species and environmental data of the CCA are presented on the F1 $\times$
F2 ordination plot (Fig. 5). The eigenvalues for the first two CCA axes were 0.45 and 0.31 and explained $55.5 \%$ of the species-environment relations. The Monte Carlo permutation test showed that the species-environment ordination was significant (first axis: $\mathrm{F}$-ratio $=8.37$, $\mathrm{P}=0.002$; overall: trace $=1.37, \mathrm{~F}=2.37, \mathrm{P}=0.002$ ) indicating that mayfly assemblages were significantly related to the tested set of environmental variables. Axis 1 was related to orthophosphates $(\mathrm{R}=0.66)$ and chemical oxygen demand $(\mathrm{R}=0.56)$, indicating that these were the most important parameters in explaining patterns of mayfly assemblages.

Additionally, a positive correlation was found between intensive agriculture and orthophosphates (Pearson's correlation coefficient; $\mathrm{r}=0.43 ; \mathrm{P}<0.01$ ), while natural and semi-natural areas correlated negatively with orthophosphates but without statistical significance.

\section{DISCUSSION}

The studied man-made lentic habitats showed relatively high total mayfly species richness, with $25 \%$ of Croatian mayfly fauna (Vilenica et al., 2015, 2016c; Dekić et al., 2016). Nevertheless, the richness per site was relatively low in comparison to the literature (Bauernfeind and Soldán, 2012; Vilenica et al., 2014; Vilenica et al., $2016 \mathrm{~b}, 2016 \mathrm{c}$ ). In addition to generally low mayfly diversity in lentic habitats, the low species richness recorded at most sites is likely the result of the strong

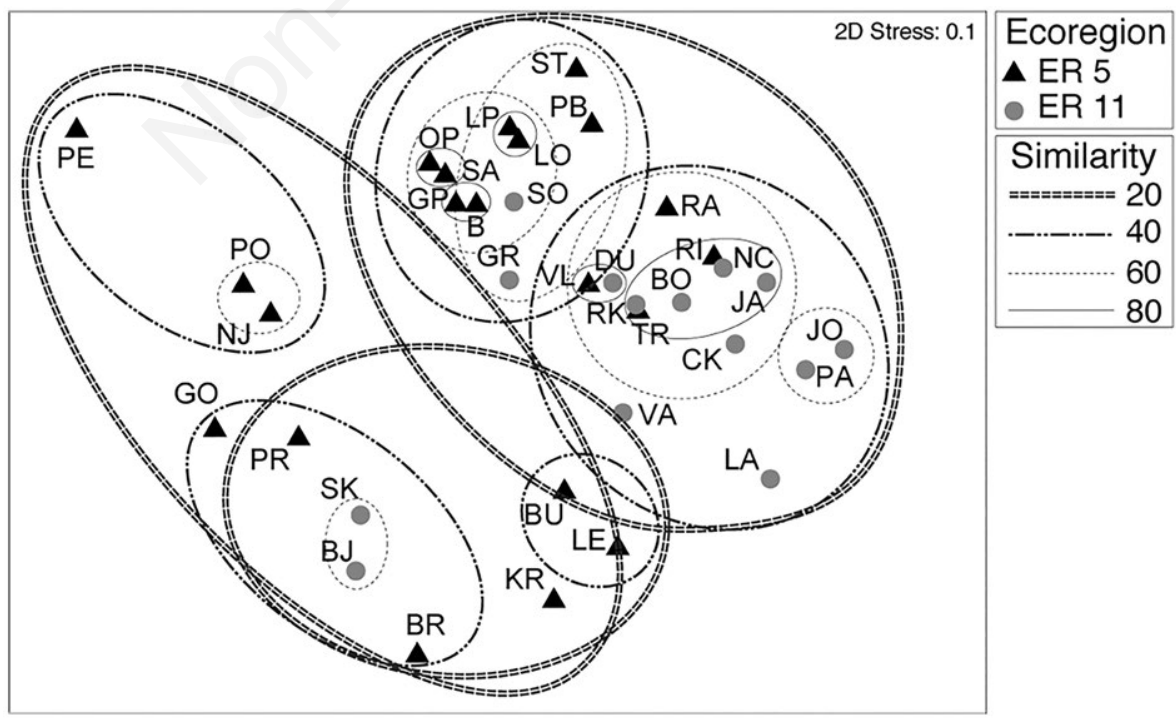

Fig. 3. Non-metric multidimensional scaling (NMDS) ordination of mayfly assemblages based on the Bray-Curtis similarity coefficient (group average linking) and their log-transformed abundances at 36 man-made lakes in Croatia. Study site abbreviations are presented in Fig. 1. 
anthropogenic pressures on these habitats, resulting in high organic and inorganic pollutant loads, high daily and seasonal water level fluctuations, low habitat heterogeneity and consequently poorer food resource diversity. Anthropogenic pressures on freshwater habitats cause loss of environmental quality by altering soil use, riparian habitats, nutrient balance, sedimentation, substrate composition (Nessimian et al., 2008), resulting in changes to species composition, abundance and assemblage structure (Allan, 2004; Yoshimura, 2012; Brasil et al. 2014).

These results indicated that the eurytopic and euryvalent Cloeon dipterum (Bauernfeind and Soldán, 2012; Buffagni et al., 2009; 2018) was the most widespread species. The predominantly lentic Caenis horaria (Bauernfeind and Soldán, 2012; Buffagni et al., 2009 ; 2018) was most abundant, which was also seen in the natural lakes in the same region (Vilenica et al., 2014). As expected, the assemblage composition mainly consisted of taxa of potamal (lower reaches) and lentic (e.g. Caenis horaria, C. lactea, C. robusta) or wide range habitat type preferences (e.g. Cloeon dipterum, Centroptilum luteolum, Ephemera danica, Serratella ignita) (Bauernfeind and Soldán, 2012; Buffagni et al., 2009; 2018). Sites under the strong influence of medium and large karst rivers (i.e., sites Brljan, Golubić, Lešće and Prančević) were an exception due to a higher percentage of spring and upper reaches (crenal and rhithral) elements. High abundance of the eurytopic Cloeon dipterum, and presence of lotic species such as

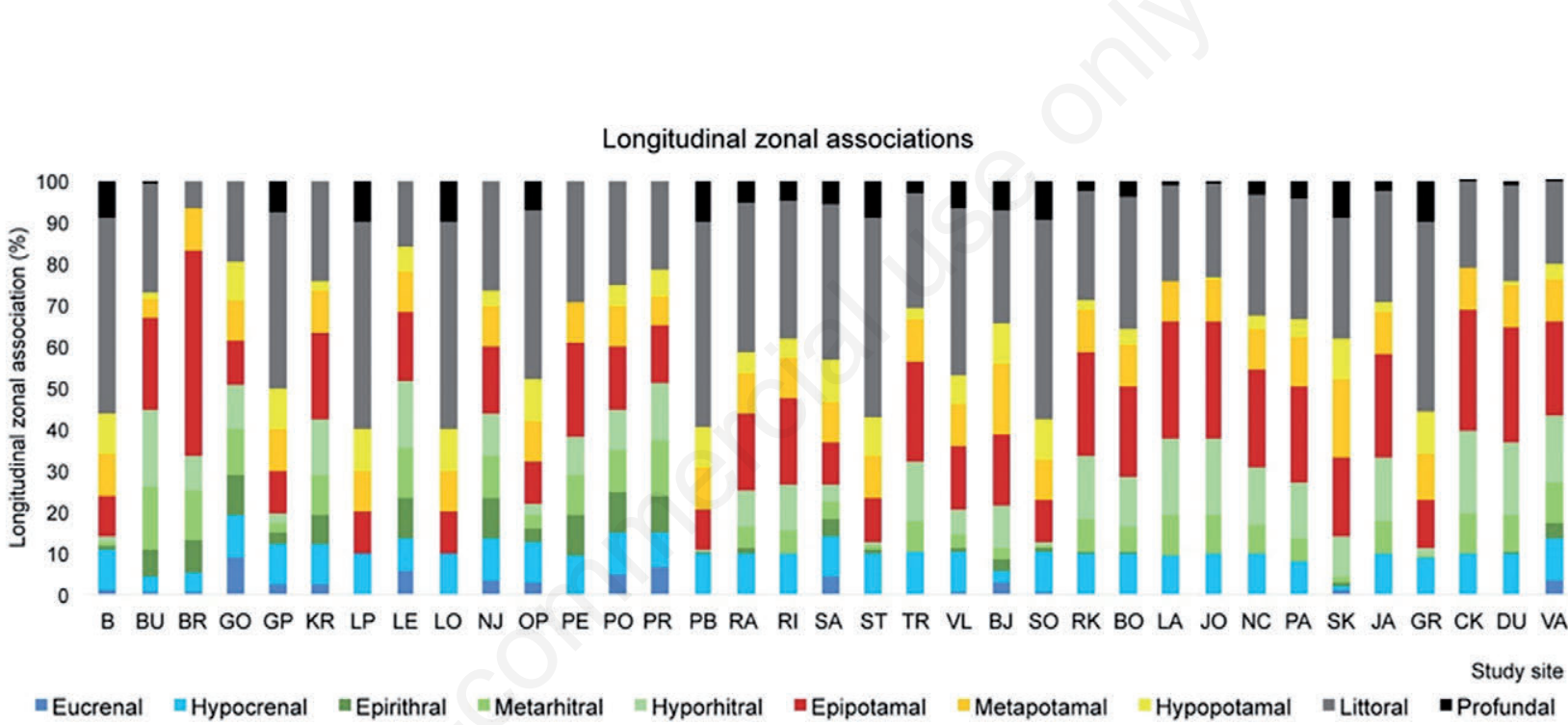

\section{a)}

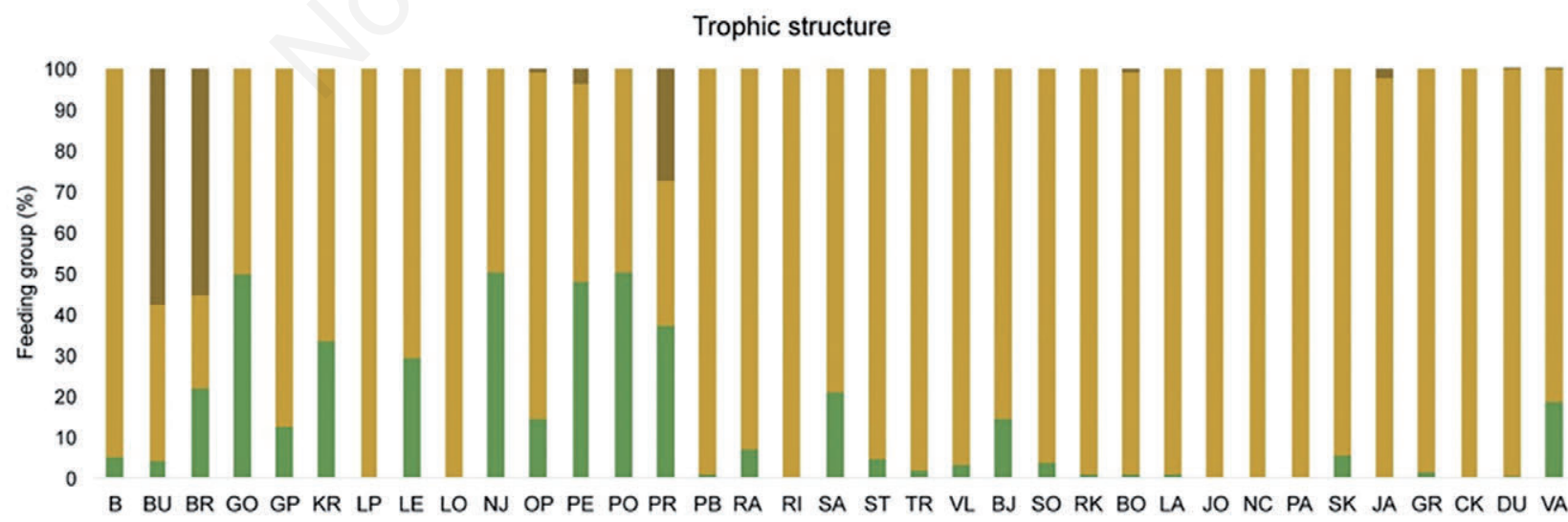

Study site

\section{b)}

Fig. 4. a) Longitudinal zonal associations and b) trophic structure of mayfly assemblages at 36 man-made lakes in Croatia. Study site abbreviations are presented in Fig. 1. 
Alainites muticus, Baetis liebenauae and Baetis rhodani were recorded (Bauernfeind and Soldán, 2012; Buffagni et al., 2009; 2018). Due to the low microhabitat diversity with a high level of sedimentation, the domination of detritivores is not surprising. Sites with higher shares of lithal and phytal (Golubić, Peruća, Njivice and Ponikve) elements had similar shares of detritivores and grazers/scrapers, due to the presence of species such as Baetis rhodani, Cloeon dipterum, C. simile, Serratella ignita (Bauernfeind and Soldán, 2012; Buffagni et al., 2009, 2018).

Due to the low number of species recorded at the majority of sites, and the rather similar species composition, the NMDS analysis showed poor separation of study sites based on mayfly assemblages. Only partial separation was observed based on the position of a site within the ecoregion, as species such as Ephemera glaucops, Baetis liebenauae and Alainites muticus were observed only in ER 5, and species such as Potamanthus luteus, Caenis lactea, Ephemera vulgata and Procloeon bifidum inhabited only man-made lakes in ER 11. This is partially in agreement with the studies of Vilenica et al. (2015) and Dekić et al.

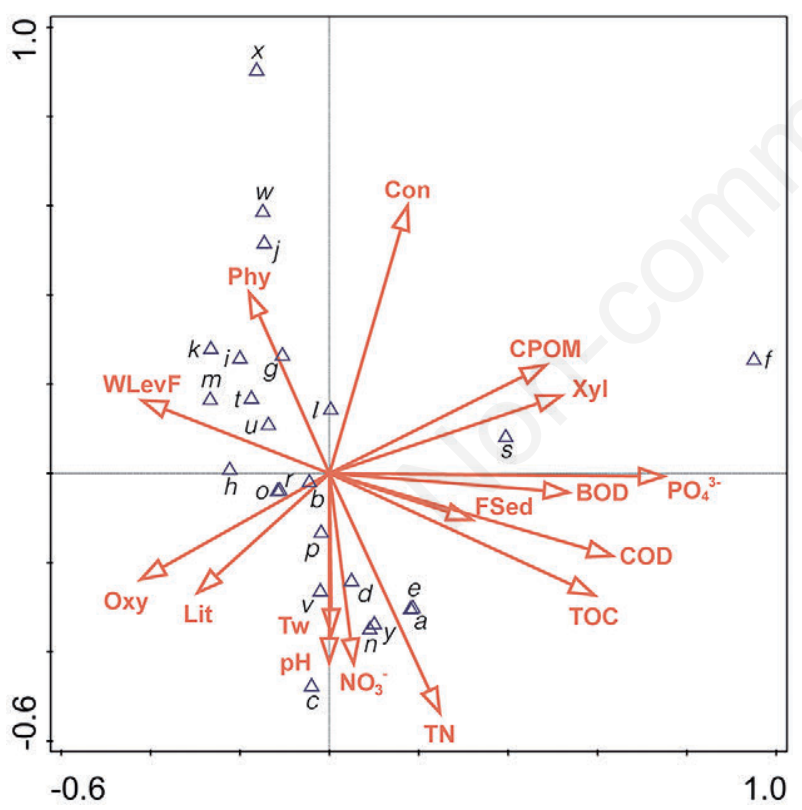

Fig. 5. F1 x F2 plane of the Canonical correspondence analysis (CCA) based on 21 mayfly taxa and 16 environmental variables. For the abbreviations of the taxa codes (blue triangle symbols) see Tab. 2. Environmental variables (red arrow symbols): Phy, phytal; WLevF, water level fluctuation; Oxy, dissolved oxygen concentration; Lit, lithal; Tw, water temperature; $\mathrm{NO}_{3}{ }^{-}$, nitrates; $\mathrm{TN}$, total nitrogen; TOC, total organic carbon; COD, chemical oxygen demand; BOD, biological oxygen demand; FSed, fine sediment; $\mathrm{PO}_{4}{ }^{3-}$, orthophosphates; Xyl, xylal; CPOM, coarse particulate organic material; Con, conductivity.
(2016), where A. muticus and C. lactea were also recorded only in ER 5 and ER 11, respectively. Other mentioned species were previously recorded from both ecoregions (Vilenica et al., 2015). Moreover, the record of E. glaucops is the first confirmation of the species presence in Croatia, as it was reported only by Bauernfeind and Soldán (2012), without reference to exact localities (see also in Vilenica et al., 2015).

Since mayflies have clear preferences for physical and chemical characteristics of their environment, such as specific water velocity, water temperature, nutrient concentrations, hydraulic conditions (Brittain and Saltveit, 1989) and river section (Buffagni et al., 2007; 2009), they are highly sensitive to habitat alteration and are among the first macroinvertebrate taxa to disappear, which was confirmed with the results of the CCA analysis. According to the analysis, mayfly assemblages were most influenced by orthophosphate concentration and chemical oxygen demand, reflecting the level of anthropogenic pollution and eutrophication, especially in ER 11. Effects of intensive agriculture on littoral benthic assemblages are indirect, such as habitat destruction and nutrient loading, which leads to eutrophication processes (Fraterrigo and Downing, 2008). Numerous studies on aquatic macroinvertebrates, including mayflies, showed that eutrophication is the main water quality problem in reservoirs leading to shifts in their biological assemblages and loss of species diversity (Vollenweider and Kerekes, 1982; Brittain and Saltveit, 1989; Wetzel, 2001; Lock and Goethals, 2013; Phillips et al., 2016; Chirwa and Chilima, 2017; Mazur et al., 2017; Buczyńska et al., 2018). Therefore, sites located in the Pannonian Lowland ecoregion are under greater influence of various kinds of pollution from land use, industry, agriculture (for 7 of 15 man-made lakes, the share of intensive agriculture in the catchment is greater than 57\%), and their mayfly assemblages are characterized by markedly lower abundances, sometimes even with lower species richness. Beketov et al. (2013) showed that in areas with intensive agricultural activities where the water was contaminated with pesticides, invertebrate species richness dropped by $42 \%$.

Annual drawdowns can decrease the taxonomic richness of benthic invertebrates and their densities are often lowest in lakes with large (e.g. $>3 \mathrm{~m})$ drawdown amplitudes (Carmignani and Roy, 2017; Grimås, 1965). Mayflies were not recorded in the Popovac Reservoir, while in the Krušćica Reservoir they were present in very low abundances (only 5 individuals per square meter). Both reservoirs are characterized by large water level fluctuations. Nevertheless, when all the investigated reservoirs were considered, no significant correlations were determined between mayfly population densities and annual changes in water level fluctuations. The samples were collected during the low water summer period, and 
we assume that mayflies, as r-selected life history strategists, can rapidly recover in this season (Brittain and Saltveit, 1989; Carmignani and Roy, 2017).

Systematic research on Croatian mayflies began relatively recently (see in Vilenica et al., 2015), which is why is our knowledge still not complete, and is growing with each new study. The results presented here are an important contribution to the knowledge of Croatian mayflies, presenting new distributional data, new habitat type preferences and tolerance to anthropogenic disturbances for the recorded species. Moreover, several species considered to be rare in Croatian freshwaters were recorded, such as Caenis lactea, Cloeon simile and Ephemera glaucops, while the find of Siphlonurus aestivalis is a new species record for the Croatian mayfly fauna (Vilenica et al., 2015, 2016b; Dekić et al., 2016), raising the number of species to a total of 83 . The species has a wide European distribution, inhabiting macrophytes or leaf litter in lentic sections of rivers, ponds and littoral zone of the lakes, usually at elevations lower than $600 \mathrm{~m}$ (Bauernfeind and Soldán, 2012). In the present study, the species was recorded in Golubić Reservoir in ER 5, as a lake strongly influenced by the Butižnica River and the presence of required microhabitats.

\section{CONCLUSIONS}

With a new species record for the country, this study showed that the knowledge of the Croatian mayfly fauna is still growing. Moreover, our results enrich the previously scarce knowledge about the relationship between littoral mayfly assemblages and environmental parameters in manmade lakes. Despite the relatively high total species richness, the number of mayfly species per site is rather low due to severe changes in habitat morphology, hydrology, and physicochemical water parameters. The difference between assemblages in the Dinaric Western Balkan ecoregion and Pannonian Lowland ecoregion was rather high, as the more polluted habitats in the Pannonian Lowland ecoregion supported much poorer mayfly assemblages, especially in terms of their abundance. Damming caused a high level of assemblage "potamalization", as they were dominated by lentic species together with species with wide ecological tolerance. Only sites under strong influence of karst rivers had slightly different assemblage composition, including lotic species.

Identifying and understanding the relationships between mayflies and environmental conditions in anthropogenically pressured habitats can contribute to species conservation, habitat management and restoration activities. Additionally, these results could be applied in creating a monitoring system for man-made lakes according to the requirements of the European Water Framework Directive.

\section{ACKNOWLEDGMENTS}

Croatian Waters are thanked for providing land use and water physicochemical data. We would like to thank our colleagues from University of Zagreb (Faculty of Science, Department of Biology, Division of Zoology) and Josip Juraj Strossmayer University of Osijek (Department of Biology) for their indispensable assistance during field investigations and for help with sorting the collected material. Miran Katar and Maja Kerovec are thanked for assisting with the artwork. Finally, we thank the the anonymous reviewers for the comments and suggestions that helped us to improve the manuscript.

\section{REFERENCES}

Allan JD, 2004. Landscapes and riverscapes: the influence of land use on stream ecosystems. Annu. Rev. Ecol. Evol. 35:257-284.

(APHA,1992. Standard Methods for the Examination of Water and Wastewater, 18th ed. Washington, DC.

AQEM Consortium, 2002. Manual for the application of the AQEM method. A comprehensive method to assess European streams using benthic macroinvertebrates, developed for the purpose of the Water Framework Directive. Version 1.0, February 2002.

Bauernfeind E, Humpesch UH, 2001. [Die Eintagsfliegen Zentraleuropas - Bestimmung und Ökologie].[Book in German]. Verlag NMW, Vienna.

Bauernfeind E, Moog O, 2000. Mayflies (Insecta: Ephemeroptera) and the assessment of ecological integrity: a methodological approach. Hydrobiologia 422:71-83.

Bauernfeind E, Soldán T, 2012. The mayflies of Europe (Ephemeroptera), Apollo Books, Ollerup.

Baxter RM, 1977. Environmental effects of dams and impoundments. Annu. Rev. Ecol. Syst. 8:255-283.

Beketov MA, Kefford BJ, Schäfer RB, Liess M, 2013. Pesticides reduce regional biodiversity of stream invertebrates. Proc. Natl. Acad. Sci. USA 2:1-5.

Brasil LS, Juen L, Cabette HSR, 2014. The effects of environmental integrity on the diversity of mayflies, Leptophlebiidae (Ephemeroptera), in tropical streams of the Brazilian Cerrado. Ann. Limnol. - Int. J. Lim. 50:325-334.

Brittain JE, Saltveit SJ, 1989. A review of the effect of river regulation on mayflies (Ephemeroptera). Regul. Rivers Res. Manage. 3:191-204.

Brittain JE, Sartori M, 2003. Ephemeroptera (Mayflies), p. 373380. In: V.H. Resh and R.T. Cardé (eds), Encylopedia of Insects. Academic Press, Amsterdam.

Buczyńska E, Szlauer-Łukaszewska A, Czachorowski S, Buczyński P, 2018. Human impact on large rivers: the influence of groynes of the River Oder on larval assemblages of caddisflies (Trichoptera). Hydrobiologia 819:177-195.

Buffagni A, Crosa G, Marchetti R, 1995. Size-related shift in the physical habitat in two mayfly species (Ephemeroptera). Freshwater Biol. 34:297-302.

Buffagni A, Cazzola M, López-Rodríguez MJ, Alba-Tercedor J, Armanini DG, 2009. Distribution and ecological preferences 
of European freshwater organisms. 3. Ephemeroptera. Pensoft Publishers, Sofia-Moscow.

Buffagni A, Armanini DG, Cazzola M, Alba-Tercedor J, LópezRodríguez MJ, Murphy J, Sandin L, Schmidt-Kloiber A, 2018. Dataset "Ephemeroptera", ver. 7.0. Accessed on: 6 April 2018. Available from: www.freshwaterecology.info

Carmignani JR, Roy AH, 2017. Ecological impacts of winter lake drawdowns on lake littoral zones: A review. Aquat. Sci. 79:803-824.

Céréghino R, Cugny P, Lavandier P, 2002. Influence of intermittent hydropeaking on the longitudinal zonation patterns of benthic invertebrates in a mountain stream. Internat. Rev. Hydrobiol. 87:47-60.

Chirwa ER, Chilima L, 2017. Use of benthic macroinvertebrate indices as bioindicators of ecosystem health for the detection of degraded landscapes in Malawi. Int. J. Agric. Forest. Fish. 5:128-134.

Clarke KR, Gorley RN, 2006. Primer V6: User Manual / Tutorial, Primer-E, Plymouth.

CLC Hrvatska, CORINE Land Cover Hrvatska, 2013. Hrvatska agencija za okoliš i prirodu.

Davies SP, Jackson SK, 2006. The biological condition gradient: a descriptive model for interpreting change in aquatic ecosystems. Ecol. Appl. 16:1251-1266.

Dekić S, Ćuk R, Belfiore C, 2016. Contribution to Croatian mayfly fauna (Insecta: Ephemeroptera). Nat. Croat. 25:101-108.

Di Giovanni MV, Goretti E, Ceccagnoli D, La Porta G, Chiappafreddo U, 2003. Ephemeroptera and Plecoptera in the Chiascio River (Central Italy) since a dam's building, $p$. 293-298. In: E. Gaino (ed.), Research update on Ephemeroptera \& Plecoptera. University of Perugia.

Elliott JM, Humpesch UH, Macan TT, 1988. Larvae of the British Ephemeroptera: a key with ecological notes. Freshwater Biological Association, Ambleside: 145 pp.

Ferro ML. Sites RW, 2007. The Ephemeroptera, Plecoptera, and Trichoptera of Missouri State Parks, with notes on biomonitoring, mesohabitat associations, and distribution. J. Kans. Entomol. Soc. 80:105-129.

Fraterrigo JM, Downing JA, 2008. The influence of land use on lake nutrients varies with watershed transport capacity. Ecosystems 11:1021-1034.

Grimås U, 1965. The short-term effect of artificial water-level fluctuations upon the littoral fauna of Lake Kultsjön, northern Sweden. Inst. Freshw. Res. Drottningholm Rep. 46:5-21

Hughes RM, Larsen DP, Omemik JM, 1986. Regional reference sites: a method for assessing stream pollution. Environ. Manage. 10:629-635.

Illies J, 1978. Limnofauna Europaea. A checklist of the animals inhabiting European inland waters, with an account of their distribution and ecology. Gustav Fischer Verlag, Stuttgart.

Irz P, Laurent A, Messad S, Pronier O, Argillier C, 2002. Influence of site characteristics on fish community patterns in French reservoirs. Ecol. Freshw. Fish. 11:123-136.

Irz, P, Odion M, Argillier C, Pont D, 2006. Comparison between the fish communities of lakes, reservoirs and rivers: Can natural systems help define the ecological potential of reservoirs? Aquat. Scie. 68:109-116.

King, RS, Baker ME, 2014. Use, misuse, and limitations of threshold indicator taxa analysis (TITAN) for natural resource management, p. 231-254. In: G.R. Guntenspergen (ed.), Application of threshold concepts in natural resource decision making. Springer, New York.

Lamp WO, Britt NW, 1981. Resource partitioning by two species of stream mayflies (Ephemeroptera: Heptageniidae). Great Lakes Entomol. 14:151-157.

Lenat DR, 1988. Water quality assessment of streams using a qualitative collection method for benthic macroinvertebrates. J. N. Amer. Benthol. Soc. 7:222-233.

Lenat DR, Penrose DL, 1996. History of the EPT taxa richness metric. J. N. Amer. Benthol. Soc. 13:305-306.

Lock K, Goethals PLM, 2013. Habitat suitability modeling for mayflies (Ephemeroptera) in Flanders (Belgium). Ecological Informatics 17:30-35.

Malzacher P, 1984. [Die Europäischen Arten der Gattung Caenis Stephens (Insecta: Ephemeroptera)].[Book in German]. Stattliches Museum für Naturkunde, Stuttgart: 48 pp.

Mazur R, Szoszkiewicz K, Nowak A, Pietruczuk K, Chmist J, 2017. Ecological classification of artificial reservoirs in Polish lowlands according to Water Framework Directive Requirements. Pol. J. Environ. Stud. 26:205-210.

Moog O, 2002. [Fauna Aquatica Austriaca].[Book in German]. Wassserwirtschaftskataster, Bundesministerium für Landund Forstwirtschaft, Umwelt und Wasserwirtschaft, Vienna.

Nessimian JL, Venticinque EM, Zuanon J, De Marco P, Gordo M, Fidelis L, Batista JD, Juen J, 2008. Land use, habitat integrity, and aquatic insect assemblages in Central Amazonian streams. Hydrobiologia 614:117-131

Peterlin M, Urbanič G, 2013. A Lakeshore Modification Index and its association with benthic invertebrates in alpine lakes. Ecohydrology 6:297-311.

Petrere M, 1996. Fisheries in large tropical reservoirs in South America. Lakes Reservoirs 2:111-133.

Petts GE, 1984. Impounded rivers: perspectives for ecological management. J. Wiley, Chichester: 326 pp.

Phillips ID, Pollock MS, Chivers DP, 2016. Benthic communities through the construction of a major reservoir and 40 years of change. Fundam. Appl. Limnol. 188:279-288.

Poff NL, Zimmermann JKH, 2010. Ecological responses to altered flow regimes: a literature review to inform the science and management of environmental flows. Freshwater Biol. 55:194-205.

Polak J, 2004. Nitrification in the surface water of the Włocławek Dam Reservoir. The process contribution to biochemical oxygen demand (N-BOD). Pol. J. Environ. Stud. 13:415-424.

Schmidt-Kloiber A, Hering D, 2015. www.freshwaterecology.info - An online tool that unifies, standardises and codifies more than 20,000 European freshwater organisms and their ecological preferences. Ecol. Indic. 53:271-282.

Schwarz U, 2012. Balkan rivers - The blue heart of Europe. Hydromorphological status and dam projects report, Vienna.

Seaman W, Sprague LM, 1991. Artificial habitats for marine and freshwater fisheries. Academic Press, San Diego: 267 pp.

StatSoft, 2010. STATISTICA 10.0 for Windows. StatSoft Inc., Tulsa.

Stoddard JL, Herlihy AT, Peck DV, Hughes RM, Whittier TR, Tarquinio E, 2008. A process for creating multimetric indices for large-scale aquatic surveys. J. N. Am. Benthol. Soc. 27:878-891. 
ter Braak, CJF Smilauer P, 2012. CANOCO reference Manual and user's Guide: Software for ordination, ver. 5.0. Microcomputer Power, Ithaca.

Urbanič G, Petkovska V, Pavlin M, 2012. The relationship between littoral benthic invertebrates and lakeshore modification pressure in two alpine lakes. Fundam. Appl. Limnol. 180:157-173.

Vilenica M, Alegro A, Koletić N, Mihaljević Z, 2016a. New evidence of Lindenia tetraphylla (Vander Linden, 1825) (Odonata, Gomphidae) reproduction at the north-western border of its distribution. Nat. Croat. 25:287-294.

Vilenica M, Brigić A, Kerovec M, Gottstein S, Ternjej I, 2016 b. Spatial distribution and seasonal changes of mayflies (Insecta, Ephemeroptera) in a Western Balkan peat bog. Zookeys 637:135-149.

Vilenica M, Brigić A, Sartori M, Mihaljević Z, 2018. Microhabitat selection and distribution of functional feeding groups of mayfly larvae (Ephemeroptera) in lotic karst habitats. Knowl. Manag. Aquat. Ecosyst. 419:1-12.

Vilenica M, Gattolliat J-L, Ivković M, Kučinić M, Mičetić Stanković V, Mihaljević Z, Sartori M, 2014. The mayfly fauna (Insecta, Ephemeroptera) of the Plitvice Lakes
National Park, Croatia. Nat. Croat. 23:349-363.

Vilenica M, Gattolliat J-L, Mihaljević Z, Sartori M, 2015. Croatian mayflies (Insecta, Ephemeroptera): species diversity and distribution patterns. Zookeys 523:99-127.

Vilenica M, Previšić A, Ivković M, Popijač A, Vučković I, Kučinić M, Kerovec M, Gattolliat J-L, Sartori M, Mihaljević Z, 2016c. Mayfly (Insecta: Ephemeroptera) assemblages of a regulated perennial Mediterranean river system in the Western Balkans. Biologia 71:1038-1048.

Vollenweider RA, Kerekes J, 1982. Eutrophication of waters, monitoring, assessment and control. OECD, Paris.

Wang Z, Hu C, 2009. Strategies for managing reservoir sedimentation. International Journal of Sediment Research 24:369-384.

Wetzel RG, 2001. Limnology. Lake and River Ecosystems. Academic Press, San Diego: 1006 pp.

Wiatkowski M, 2011. Influence of słup dam reservoir on flow and quality of water in the Nysa Szalona river. Pol. J. Environ. Stud. 20:469-478.

Yoshimura M, 2012. Effects of forest disturbances on aquatic insect assemblages. Entomol. Sci. 15:145-154. 